\title{
Using the Right Tool: David Woodward's Suggested Framework and the Study of Military Cartography
}

Joel Douglas Radunzel

Syracuse University

jidradunz@syr.edu

In 1974 David Woodward suggested a framework for organizing the study of the history of cartography that unified on one hand the process and the output of cartographic production, and on the other hand the four sequential phases of cartographic production, from information gathering through document use. In a survey of scholars who have cited Woodward's model I note that, while this framework has influenced the conceptual development of map history, it has rarely been applied rigorously to specific instances of mapping. I argue that this model is an underutilized tool in cartographic scholarship, and that Woodward's matrix is ideally suited to examining how military units carry out mapping. Because military units, particularly large ones, are in effect self-contained systems that cyclically produce, use, and reproduce their own maps, I contend that scholars can modify Woodward's original model in content, though not in structure, to study military mapping activities. To illustrate this point, I present as a case study the British military's Egyptian Expeditionary Force (EEF) during the Gaza Campaign of late 1917. This force performed a broad range of mapping activity, much of it innovative. A modification of the Woodward framework that brings together the specific elements of the $E E F$ 's information gatherers, information processors, and map users into a single cohesive cartographic system illustrates the value and utility of this framework for studying the history of military cartography.

KEYWORDS: military geography; military cartography; history of cartography; David Woodward (1942-2004)

\section{INTRODUCTION}

The DiCTUM THAT any work can be made easier if one first takes the time to select and use the proper tool is as applicable to academic research as to any other activity. One conceptual tool that has remained largely unused in the metaphorical toolbox of academic cartographers is David Woodward's (1974) suggested framework for studying the history of cartography. Recent renewed interest in the history and practice of military cartography, prompted partially by the centenary of World War I, has highlighted an area of study that can benefit substantially from this old but still powerful tool. Woodward's framework is well suited to studying military cartography because it accommodates the cyclical patterns of military mapmaking and generally conforms to the structure of military organizations and operations. Furthermore, the usefulness of Woodward's matrix as a conceptual framework indicates its broader applicability for studying how military organizations view and map their surroundings. As such, this article examines how Woodward's schema can be applied to the academic study of military mapmaking and argues that it is indeed the right tool for approaching this type of cartographic endeavor.

What recommends Woodward's structure over other cartographic models for the study of military mapmaking is how it incorporates actors who contribute to the cartographic process but do not participate directly in mapmaking. This contrasts with other, simpler models for conceptualizing mapmaking such as that put forward by P. C. Muerhcke (1972) and elaborated upon by Arthur Robinson and Barbara Petchenik $(1975,99)$ and Harold Moellering (1980, 14). Whereas these other models focus heavily on the map and the information that it communicates, Woodward's model explores more fully how this information is gathered, analyzed, and used. These differences give Woodward's framework a distinct advantage in 
the context of military cartography, in which the information being mapped is often difficult to gather and ambiguous. Furthermore, the resulting map product is usually put to immediate use in ways that prompt renewed mapping activity. Thus, Woodward's emphasis on data gathering and analysis, as well as on map use, leaves his model better suited for studying military cartography. Moreover, one of its best uses is translating military jargon and organizational complexity into terms more accessible to people outside the military community.

Indeed, military cartography appears to be isolated from the broader cartographic and geographic fields, at least in the US academic community. With a few notable exceptions (e.g., Pearson 2002; Schulten 2012; Fedman and Karacas 2012) academic cartographers have engaged only tangentially with the maps produced by military organizations. Rachel Woodward, in her article outlining emerging research in military geography, noted that almost no studies have addressed how military units view and conceptualize terrain (Woodward 2014, 48). Furthermore, Cheryl McGeachan has noted that the centenary of World War I provides an opportunity to study various geographical facets of that conflict, including how militaries view and visualize battlefields (McGeachan 2014, 827). Even so, neither of these scholars advocated David Woodward's framework as a tool to address these gaps in knowledge.

Woodward's (1974) article has been praised for looking beyond map content to the actual production process, as well as the form of the maps as artifact, and creating a unified system that examines not just how maps are created but also how they are used (Edney 2005, 19). But despite its impact on conceptual thinking, Woodward's suggested framework - concisely laid out in a series of matrices-has exerted little influence on how researchers have structured their projects.

The isolation of academic military cartography and the underutilization of Woodward's framework may be interrelated. Indeed, they provide an exciting opportunity to wade into a largely-unexplored field of cartographic endeavor (Woodward 2014, 47). One reason for the scholarly isolation of military cartography may be the lack of a proper tool for academics to approach what to most must be a very foreign culture in the military community (McGeachan 2014, 826-7). Similarly, Woodward's suggested framework may have remained generally unused because few non-military research topics are well-suited for its application. By contrast, I argue here that Woodward's framework is particularly useful for studying how military organizations produce and use maps.

Military organizations produce maps internally at a prodigious rate and across a broad range of subjects, from complicated assaults using diverse weapon systems to mandated environmental impact statements and even base landscape beautification. These map products are used throughout the entire military decision-making process, from operational planning through after-action reviews, which in turn influence the creation of yet more maps in a continuous cartographic cycle. Furthermore, Woodward's fourrow matrix mirrors the influential observe-orient-decide-act (OODA) loop suggested by US Air Force colonel John Boyd (Hammond 2004, 1). The OODA loop model has exerted a powerful influence on military thinking in recent decades, and its mark can be seen on how US Army doctrine conceives and communicates the flow of military operations (Mostaghni 2010, 49; US Army 2012, vi). This cyclic activity makes Woodward's framework a powerful tool for studying military cartography and, by extension, how military units and individuals look at landscapes.

To illustrate these arguments, this paper presents an examination of the operational mapmaking conducted by the British Army's Egyptian Expeditionary Force (EEF) during the $3^{\text {rd }}$ Battle of Gaza-fought on the Palestinian Front of World War I-as a case study to demonstrate how Woodward's framework can be applied to the study of military cartography. Specifically, the EEF created a series of "operation" maps throughout the October-December 1917 Gaza battle to track the locations of their own units and those of their Turkish opponents. These maps were notable in that they differed substantially from other "order-of-battle" and "situation" or "position" maps produced by the various belligerents during the war and also because the British $7^{\text {th }}$ Field Survey Company-the cartographic component of the EEF-issued an edition of these maps every day during the entire six-week course of the campaign, with each succeeding map materially influenced by those that preceded it (Collier 2008, 10). These maps were the product of a military intelligence/cartography system that provides an ideal setting for applying Woodward's framework. 


\section{DAVID WOODWARD'S SUGGESTED FRAMEWORK AND ITS PLACE IN CARTOGRAPHIC SCHOLARSHIP}

IN HIS I974 ARTICLE, David Woodward suggested a framework for studying cartography that divided the production, distribution, and use of maps into four consecutive phases (Table 1). These phases are represented by horizontal rows on the table: information gathering, information processing, document distribution, and document use. Each row is then divided into two vertical columns that account for the process of production and the resulting product. The production column is further subdivided to account for the personnel, techniques, and tools active within each row of the table. This model is cyclical, both within and between phases, insofar as the product from each phase-and also each line within the phases-informs both the form and content of the subsequent cartographic activities (Woodward 1974, 109). In many casesand particularly in military cartography-the entire mapmaking process is cyclic, with each final map product initiating a new mapping cycle.

As Matthew Edney $(2005,23)$ has noted, Woodward's framework was a key influence in moving the cartographic discipline away from its historical roots-attempts to create a science of mapmaking and the study of map content-towards a humanistic approach that allowed a more critical examination of historical maps and the processes and circumstances that created them (Harley 1989a, 3). It accomplished this not by nullifying the study of map content, but by integrating this study-defined by the product column of the framework-with the form of the maps, which permeates the entire matrix, most prominently in the production columns (Edney 2005, 20). Woodward's matrix also encourages scholars to classify map history studies within one or more cells of the table (Woodward 1974, 114). The penultimate expression of Woodward's humanistic influence on the academic discipline of cartography is the ongoing effort to create the multi-volume encyclopedic History of Cartography, which broadly emphasizes the history of the mapping process in the growth of the cartographic field and examines historically each cell of the mapping process (Freundlich 2011, 341).

More specifically, Woodward's framework has been influential in the scholarship of numerous academics, most notably his peer, J. B. Harley (1989b), but also many others, including Arthur Robinson and Barbara Petchenik in their 1975 Cartographica article, and Lydia Pulsipher (1987). It was also the subject, initially, of criticism that its structure failed to account for the cultural and historical context in which maps are created and used and that it overemphasized production over product (form over content), issues that Woodward addressed in his later scholarship (Edney 2005, 20).

That said, perhaps the most potent criticism of Woodward's framework may be that it has been rarely used to frame an in-depth research project. When the framework has been used, it has general served to classify a scholar's contribution within the larger structure of a cartographic system, rather than to provide internal structure for the research project. Even so, a good example of a broad application of Woodward's framework to structure a project is Pulsipher's (1987) examination of $17^{\text {th }}$-century mapping on the island of Montserrat. However, she acknowledges that, though Woodward's thinking influenced her entire project, she only utilized portions of his framework (Pulsipher 1987, 421). A broad survey of cartographic literature, including review articles by Mark Monmonier (2007), and by Michael Finn and Diana Thunen (2013), failed to locate other scholars who have used Woodward's model to structure their research. So, why the limited application of his framework?

The answer to this question lies partially in the fact that not every map and not every cartographic process lends itself to the full application of this model. Woodward himself noted that "many maps do not progress beyond the manuscript stage, but they are nevertheless subject to distribution.... and eventual use by the reader" (Woodward 1974, 113). Of course, many mapping systems have products that never reach their intended recipients. Indeed, in the civilian sphere, a broadly diverse community of users often creates a decentralized system not readily accommodated by the Woodward framework. One could further argue that the contents of the matrix are too specific or rigid to keep pace with the technological advances in mapmaking that have occurred in recent decades. Regardless of the reason, over the past four decades scholars have decided - either deliberately or by default — that Woodward's framework was not an appropriate tool for structuring their research. 


\begin{tabular}{|c|c|c|c|c|}
\hline \multirow{4}{*}{$\begin{array}{c}\text { Information } \\
\text { Gathering }\end{array}$} & \multicolumn{3}{|c|}{ Production } & \multirow{2}{*}{ Product } \\
\hline & Personnel & Techniques & Tools & \\
\hline & Observer & Observation & $\begin{array}{c}\text { Physical and Mental } \\
\text { Faculties }\end{array}$ & Image \\
\hline & Surveyor & $\begin{array}{c}\text { Surveying } \\
\text { Data Gathering }\end{array}$ & $\begin{array}{l}\text { Surveying Instruments, } \\
\text { Questionnaires, etc. }\end{array}$ & Data \\
\hline \multirow{5}{*}{$\begin{array}{l}\text { Information } \\
\text { Processing }\end{array}$} & Designer & Design & Design Tools & Specifications \\
\hline & Editor & Compilation & Compilation Tools & Worksheet \\
\hline & Draftsman & Drafting & Drafting Tools & Manuscript \\
\hline & Engraver & Engraving & Engraving Tools & Plate \\
\hline & Printer & Printing & Presses, etc. & Printed Map \\
\hline \multirow{2}{*}{$\begin{array}{l}\text { Document } \\
\text { Distribution }\end{array}$} & Publisher & Publishing & Publishing Facilities & Published Map \\
\hline & Seller & Marketing & Marketing Facilities & Marketed Map \\
\hline \multirow{4}{*}{$\begin{array}{c}\text { Document } \\
\text { User }\end{array}$} & & Acquisition & & \\
\hline & Librarian & Storage & Library Facilities & Map \\
\hline & & Retrieval & & \\
\hline & User & Interpretation & $\begin{array}{c}\text { Physical and Mental } \\
\text { Faculties }\end{array}$ & Image \\
\hline
\end{tabular}

Table 1. David Woodward's suggested framework for studying the history of cartography (from Woodward [1974]). 
By contrast, the mapping process in military organizations is markedly more centralized, with units gathering and analyzing data, making and distributing maps (paper and digital), and using these maps to plan and conduct operations that generate further data, which must in turn be processed and mapped (Armenis 2010, 207). These comments refer generally to large-scale tactical and operational maps used by individual units as opposed to small-scale strategic maps used for matters of national policy. As an example, the staff of a present-day US infantry battalion (approximately 700-800 soldiers) planning an operation will create and distribute maps dealing with cross-country mobility, expected enemy positions, planned friendly maneuvers, planned artillery fire, medical evacuation schemes, resupply schemes, communication networks, the employment of aerial assets, and any number of other relevant topics (US Army 2010, 2-1 to 2-14). These all inform operations that, one way or another, alter the staff's understanding of the battleground so that a new cycle of mapping and map distribution is required to keep abreast of the changes. Woodward's suggested framework is an excellent tool for studying and analyzing this type of mapmaking. However, making the model relevant requires a modification of Table 1 to better reflect the organizational structure of a military unit.

\section{MODIFYING WOODWARD'S FRAMEWORK TO REFLECT MILITARY ORGANIZATIONS}

Whereas THE CELLS in Woodward's table are necessarily generic in content and focused on the traditional civil and commercial spheres of mapping, military mapping requires several adjustments. Accordingly, Table 2 is a modification designed to represent the cartographic system of a generic military formation. This table would be appropriate for examining almost any military unit that makes maps currently or in the past. The following section details the differences between this generic military framework and Woodward's original matrix. Later, the EEF case study will demonstrate this modification's usefulness in historical research.

Beginning in the production column of the information-gathering phase, in the "Personnel" sub-column the generalized "observer" and "surveyor" entries are replaced with their military equivalents: reconnaissance troops, who scout for the enemy ahead of the main force, and technical intelligence-gathering means such as signal intercepts and aerial reconnaissance. Obviously this latter source is very broad and has evolved as technology has advanced, but the mission of scouting forces has actually changed little since antiquity. Since modern militaries (World War I and later) are generally less concerned with mapping terrain than with populating maps with tactically and operationally relevant information, the surveying element of Woodward's table disappears in these cells. The "techniques" column contains the broad methods-both tactical and technical-by which these information-gathering entities operate, just as the "tools" column contains their generic equipment. The products of this phase in Table 2 are the reports sent back by the scouting forces and the information gathered by technical means. These represent fragmentary pieces of data that require analysis to craft them into useful intelligence, a process that occurs in the information-processing phase.

This next row of this modified framework focuses on those individuals who first decide what information is relevant to transmit back to higher headquarters-itself an act of analysis - and the staff officers and commanders who analyze the data received. Military officers use standardized procedures (doctrine) to guide them in this analysis, but also have leeway for their own decision-making (US Army 2012, 2-5). The products of this phase include planning priorities issued by commanders to guide the work of the staff officers, as well as summaries that distill the diverse raw data into a useful common picture of the area of operations, perhaps in the form of pre-distribution draft maps. The graphic representation and dissemination of this picture in a final polished map occurs in the document-distribution phase.

Military mapmaking has long been the responsibility of headquarters staff, but prior to World War I, military cartographers had generally focused their efforts on charting physical terrain, whereas during and after this conflict the emphasis shifted to plotting tactical and operational information on pre-existing maps, and distributing these maps to subordinate units through an established chain of command (Collier 1994, 101-3; Collier and Inkpen 2001, 145). In this endeavor, militaries have developed standardized map symbols to streamline cartographic communication and reduce confusion (US Army 2004, vi). These 


\begin{tabular}{|c|c|c|c|c|}
\hline \multirow{4}{*}{$\begin{array}{l}\text { Information } \\
\text { Gathering }\end{array}$} & \multicolumn{3}{|c|}{ Production } & \multirow{2}{*}{ Product } \\
\hline & Personnel & Techniques & Tools & \\
\hline & $\begin{array}{l}\text { Reconnaissance } \\
\text { Forces }\end{array}$ & $\begin{array}{c}\text { Patrols } \\
\text { Observation }\end{array}$ & $\begin{array}{c}\text { Physical and Mental } \\
\text { Faculties } \\
\text { Vehicles } \\
\text { Optics }\end{array}$ & Situation Reports \\
\hline & $\begin{array}{l}\text { Technical Intelligence- } \\
\text { gathering Means }\end{array}$ & $\begin{array}{c}\text { Signal Intercepts, } \\
\text { Image Intelligence, } \\
\text { Electronic Intelligence, } \\
\text { etc. }\end{array}$ & $\begin{array}{l}\text { Radios, Aircraft, } \\
\text { Cameras, Sensors, } \\
\text { etc. }\end{array}$ & Raw Data \\
\hline \multirow{3}{*}{$\begin{array}{l}\text { Information } \\
\text { Processing }\end{array}$} & Unit Leaders & $\begin{array}{c}\text { Physical and Mental } \\
\text { Faculties }\end{array}$ & Report Formats & Operational Priorities \\
\hline & $\begin{array}{l}\text { Communication } \\
\text { Specialists and } \\
\text { Couriers }\end{array}$ & Data Transmission & $\begin{array}{l}\text { Communication } \\
\text { Networks }\end{array}$ & Compiled Reports \\
\hline & Staff Officers & $\begin{array}{l}\text { Military Decision- } \\
\text { Making Process }\end{array}$ & $\begin{array}{l}\text { Military Doctrine } \\
\text { Training }\end{array}$ & $\begin{array}{c}\text { Intelligence } \\
\text { Summaries } \\
\text { Recommendations } \\
\text { Common Operating } \\
\text { Picture }\end{array}$ \\
\hline \multirow{2}{*}{$\begin{array}{l}\text { Document } \\
\text { Distribution }\end{array}$} & Staff Mapmakers & $\begin{array}{c}\text { Standard Symbols } \\
\text { and Forms }\end{array}$ & $\begin{array}{l}\text { Physical and Digital } \\
\text { Mapmaking Tools }\end{array}$ & $\begin{array}{l}\text { Tactical, Operations, } \\
\text { and Logistical Maps }\end{array}$ \\
\hline & $\begin{array}{l}\text { Communication } \\
\text { Specialists and } \\
\text { Couriers }\end{array}$ & $\begin{array}{l}\text { Intelligence } \\
\text { Distribution } \\
\text { Operation Orders }\end{array}$ & Chain of Command & Operations Orders \\
\hline \multirow{2}{*}{$\begin{array}{c}\text { Document } \\
\text { User }\end{array}$} & Unit Leaders & $\begin{array}{l}\text { Military Decision- } \\
\text { Making Process }\end{array}$ & $\begin{array}{l}\text { Physical and Mental } \\
\text { Faculties }\end{array}$ & $\begin{array}{l}\text { Unit Orders and } \\
\text { Operations }\end{array}$ \\
\hline & Tactical Military Units & Tactical Operations & $\begin{array}{l}\text { Tactical Doctrine and } \\
\text { Training }\end{array}$ & More Intelligence \\
\hline
\end{tabular}

Table 2. Woodward's framework modified to reflect the structure of generic military cartographic systems. 
symbols communicate intelligence, analysis, and intentions to subordinates or-in the case of upward flowing information-to superiors.

In the document-use phase, subordinate commanders and units use the maps produced by the headquarters staff to plan and execute operations that move forces into contact with the enemy (or not) and thus alter the battlefield conditions - or at least the perception thereof-in one way or another. This in turn generates reports from these formations back up the chain of command, providing raw data that initiate a new planning and mapping cycle. This phase differs perhaps more than any other from the content of Woodward's matrix. In his framework, the final product is deposited in a library for general access and reference, to be used for some as-yet unspecified future task, perhaps unrelated to the original purpose of the map. Military maps, in contrast to their civilian counterparts, are generally created for an immediate purpose under rapidly changing conditions and are thus more immediately useful. This fact highlights the cyclic nature of military cartographic systems.

Each of the four phases in this military cartographic system builds on the preceding phase, though they may occur concurrently. And as Woodward noted about his original framework, not every step of this military mapping cycle will necessarily occur in every case. Often a map might remain in draft form for use solely by the headquarters staff. Moreover, because of a dearth of reconnaissance information, staff officers might be forced to plot speculative or otherwise questionable information (US Army 2012,
9-10). Even so, the defining characteristic of this system is that it is cyclical, with each map and mapping cycle materially influencing the content of subsequent map products.

Perhaps the ultimate modern expression of this system is the networked digital moving map display fielded by the US military. This technology (a dual system called FBCB2/Blue Force Tracker) equips combat vehicles and command posts with a computer terminal that networks with other vehicles and headquarters equipped with the same system. Linked to a GPS receiver, the terminal automatically transmits the location of the vehicle across a digital radio network and receives and plots the location of all other similarly equipped friendly units. Furthermore, the soldier operating the system can manually plot observed enemy forces or obstacles directly onto the digital map (Armenis 2010, 207). This information is then transmitted to an appropriate headquarters for approval before being broadcast across the entire network, ensuring that every sub-unit possesses a common operational picture of the battlefield situation and allowing commanders to rapidly respond to changing tactical conditions (US Army 2010, 5-5). At times, this mapping cycle can occur in seconds.

Recent technology has drastically shortened the military mapping cycle, but its actual form and concept are not new. One clear application of this cartographic concept is the operation mapping technique practiced by the EEF in Palestine during the $3^{\text {rd }}$ Battle of Gaza in late 1917. This battle is an excellent case study for demonstrating both the cyclical nature of military mapping and the relevance of Woodward's cartographic framework.

\section{THE EEF'S OPERATION MAPS: A CARTOGRAPHIC CASE STUDY}

The Egyptian Expeditionary Force's (EEF) cartographic effort during the $3^{\text {rd }}$ Battle of Gaza was a sophisticated process given the relatively primitive technology available at the time. During the six weeks that this battle raged-from late October to mid-December 1917-the EEF's intelligence staff and the $7^{\text {th }}$ Field Survey Company (FSC) produced a series of operation maps showing the positions of friendly units and opposing Turkish forces, with a new edition of the map printed and distributed every day. A complete set of the original editions of this map series are in the British National Archives filed as WO 153/1035/2 and WO 153/1043. The transformation of raw data into a polished operation map is an excellent example of the military cartographic cycle and exemplifies the modification of Woodward's framework seen in Table 2.

This section first illustrates how the modified cartographic model conceptually organizes the production of the operation maps by the EEF (Table 3). It then assesses the value of a rigorous application of Woodward's framework, which demonstrates this model's applicability to military cartography. The section then concludes with some brief comments on the effectiveness of the operation mapping cycle as practiced by the EEF, including the limitations imposed by the available technology and the structure of 


\begin{tabular}{|c|c|c|c|c|}
\hline \multirow{6}{*}{$\begin{array}{l}\text { Information } \\
\text { Gathering }\end{array}$} & \multicolumn{3}{|c|}{ Production } & \multirow{2}{*}{ Product } \\
\hline & Personnel & Techniques & Tools & \\
\hline & Intelligence Officers & Signal Intercepts & Wireless Sets & $\begin{array}{l}\text { Intercepted } \\
\text { Messages }\end{array}$ \\
\hline & $\begin{array}{c}\text { Aerial and Ground } \\
\text { Patrols }\end{array}$ & $\begin{array}{l}\text { Ground and Aerial } \\
\text { Reconnaissance }\end{array}$ & $\begin{array}{l}\text { Aircraft, Cameras, } \\
\text { Optics }\end{array}$ & $\begin{array}{l}\text { Aerial Photographs, } \\
\text { Patrol Reports }\end{array}$ \\
\hline & Interrogators & $\begin{array}{l}\text { Prisoner/Deserter } \\
\text { Interrogations }\end{array}$ & Mental Faculties & $\begin{array}{l}\text { Prisoner/Deserter } \\
\text { Statements }\end{array}$ \\
\hline & Agent Networks & Train Watching & $\begin{array}{l}\text { Communication } \\
\text { Networks }\end{array}$ & Agent Reports \\
\hline \multirow{3}{*}{$\begin{array}{l}\text { Information } \\
\text { Processing }\end{array}$} & $\begin{array}{l}\text { Communication } \\
\text { Specialists }\end{array}$ & $\begin{array}{l}\text { Situation and } \\
\text { Intelligence Reports }\end{array}$ & $\begin{array}{l}\text { Report Formats and } \\
\text { Communication } \\
\text { Networks }\end{array}$ & Situation Reports \\
\hline & Intelligence Officers & $\begin{array}{l}\text { Multi- and Single- } \\
\text { Source Analysis } \\
\text { Methods }\end{array}$ & $\begin{array}{l}\text { Mental Faculties, } \\
\text { Standardized Forms }\end{array}$ & $\begin{array}{l}\text { Intelligence } \\
\text { Summaries }\end{array}$ \\
\hline & & $\begin{array}{c}\text { Compilation, } \\
\text { Drafting, Engraving, } \\
\text { Printing Tools }\end{array}$ & $\begin{array}{l}\text { Pre-printed Base } \\
\text { Maps, Colored } \\
\text { Engraving Plates }\end{array}$ & $\begin{array}{c}\text { Draft Operation } \\
\text { Maps }\end{array}$ \\
\hline \multirow{2}{*}{$\begin{array}{l}\text { Document } \\
\text { Distribution }\end{array}$} & Staff Officers & $\begin{array}{l}\text { Daily Intelligence } \\
\text { Dissemination }\end{array}$ & $\begin{array}{l}\text { Chain of Command, } \\
\text { Subordinate Staffs }\end{array}$ & Operation Orders \\
\hline & $7^{\text {th }} \mathrm{FSC}$ & $\begin{array}{c}\text { Compilation, } \\
\text { Drafting, Engraving, } \\
\text { Printing }\end{array}$ & $\begin{array}{l}\text { Pre-printed Base } \\
\text { Maps, Compilation, } \\
\text { Drafting, Engraving, } \\
\text { Printing Tools }\end{array}$ & Operation Maps \\
\hline \multirow{2}{*}{$\begin{array}{c}\text { Document } \\
\text { User }\end{array}$} & $\begin{array}{l}\text { EEF Commander, } \\
\text { Subordinate } \\
\text { Commanders }\end{array}$ & $\begin{array}{l}\text { Military Decision- } \\
\text { Making Process }\end{array}$ & $\begin{array}{l}\text { Tactical Doctrine and } \\
\text { Training }\end{array}$ & $\begin{array}{c}\text { Operation Decisions, } \\
\text { Unit Orders and } \\
\text { Movements }\end{array}$ \\
\hline & $\begin{array}{l}\text { GHQ and Corps } \\
\text { Staffs }\end{array}$ & $\begin{array}{c}\text { Enemy Capabilities } \\
\text { and Intentions } \\
\text { Analysis }\end{array}$ & $\begin{array}{l}\text { Physical and Mental } \\
\text { Faculties }\end{array}$ & More Intelligence \\
\hline
\end{tabular}

Table 3. Woodward's framework modified to reflect the specific structure of the Egyptian Expeditionary Force during the $3^{\text {rd }}$ Battle of Gaza, 1917. 
EEF mapping activity. These observations illustrate the broader import of Woodward's table in streamlining mapmaking in rapidly-changing and time-sensitive contexts.

\section{HISTORICAL CONTEXT}

The Palestine Campaign grew out of the British Empire's strategic imperative to safeguard the Suez Canal and the sea lines of communication to India. Several large Turkish raids on this waterway in the early years of World War I convinced the British of the necessity to move the front lines forward across the Sinai Peninsula. However, the forces necessary for pushing the front forward to the Palestine Frontier were also too large to justify their assignment to a purely defensive role once they reached the Ottoman border.

Accordingly, the British government commissioned the EEF's commander, General Archibald Murray, and his eventual successor, General Edmund Allenby, to invade Palestine and capture Jerusalem before Christmas 1917. The British forces under Murray attempted twice-in the $1^{\text {st }}$ and $2^{\text {nd }}$ Battles of Gaza-to breach the Turkish frontier defenses arrayed on a line stretching from the town of Gaza on the Mediterranean coast southeast to the crossroads town of Beersheba. These failures prompted the British Imperial General Staff to replace Murray with Allenby and convinced the EEF of the need to better track the locations of units in the Turkish order of battle, a need that gave rise to the operation mapping technique (Wavell 1936, 94-114; Sheffy 1998, 207-14). The EEF staff used the resulting operation maps to track the location of each British and Turkish regiment in the opposing armies' orders of battle. The maps also helped the EEF commanders make operational decisions about how to respond to Turkish troop movements, much as modern networked dynamic mapping systems help contemporary military officers oversee combat (Armenis 2010, 208).

The $3^{\text {rd }}$ Battle of Gaza occurred in three consecutive operational phases. First, the EEF under Allenby launched a thoroughly pre-planned assault on the Turkish eastern flank at Beersheba that drew the enemy reserves to that end of the line before a second assault struck the weakened Gaza defenses in the west, a sequence that was significantly informed by the information communicated through the operation maps (Figure 1; Meinertzhagen 1917, 46). In the second phase of the battle the Turkish army evacuated their defensive line and retreated northward, pursued

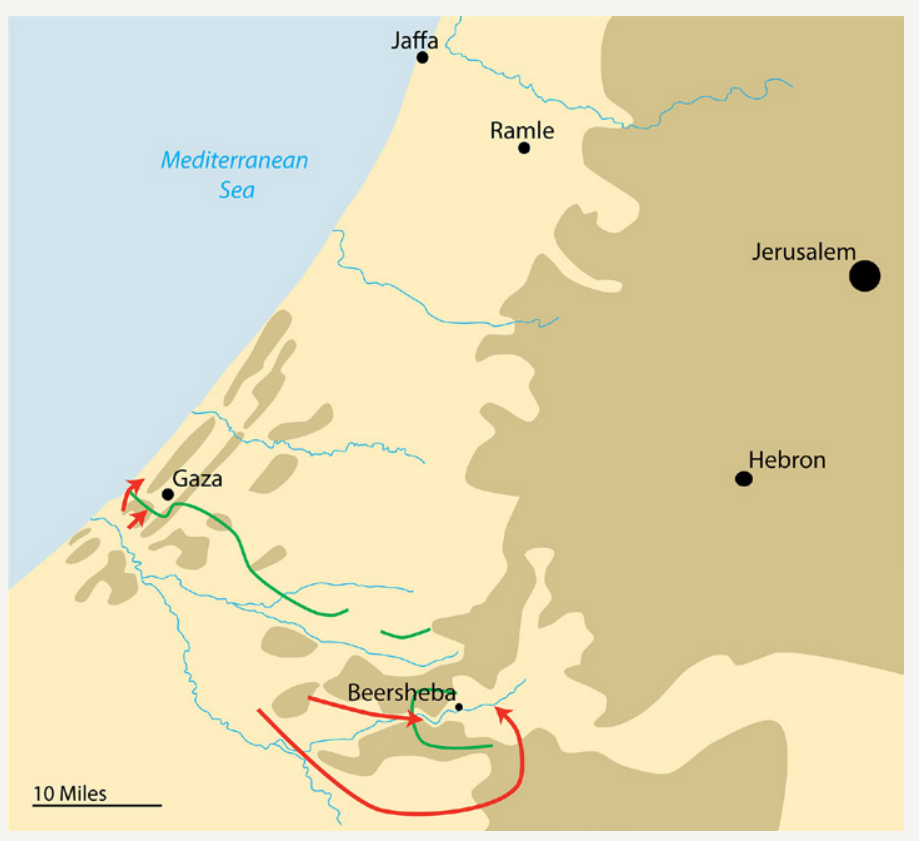

Figure 1. In the first phase of the 3rd Battle of Gaza, the British forces launched successive attacks (in red) against both flanks of the Turkish line (in green), first at Beersheba, then at Gaza.

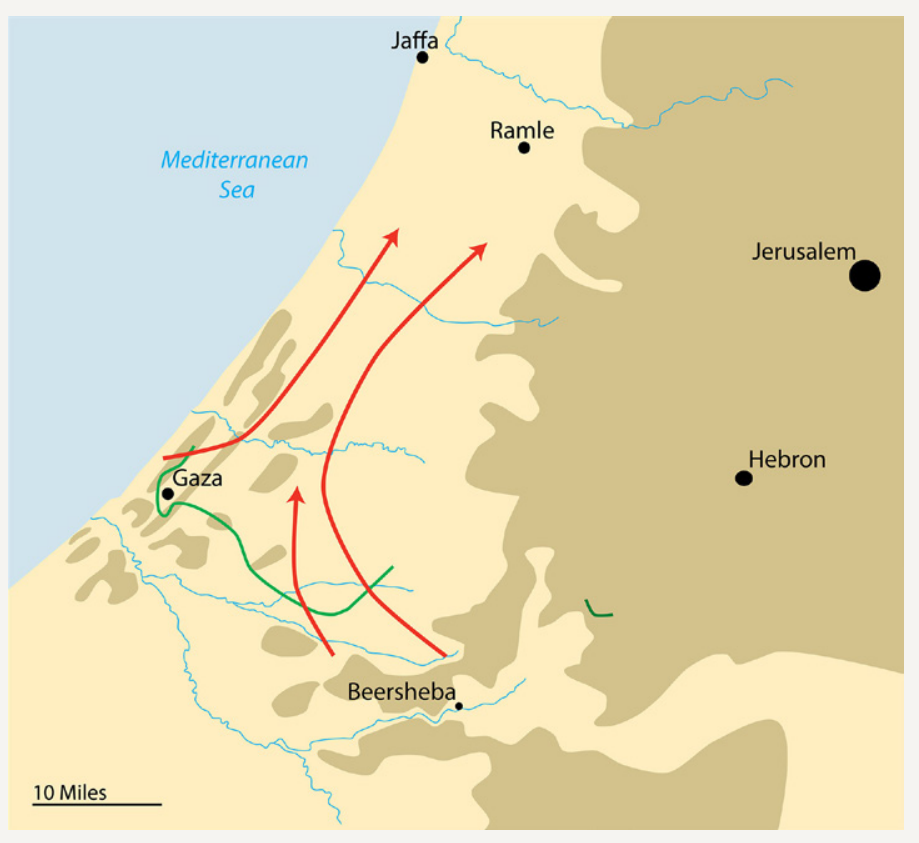

Figure 2. In the second phase, the British pursued the retreating Turkish army northward until the front stabilized on a new line running generally from Jaffa to Jerusalem.

by the British, until the front stabilized at a latitude generally running through Jerusalem (Figure 2). The operation maps were least useful during this phase as the chaotic and rapidly changing operational context meant that the twenty-four hour operation-mapping cycle was too slow to 


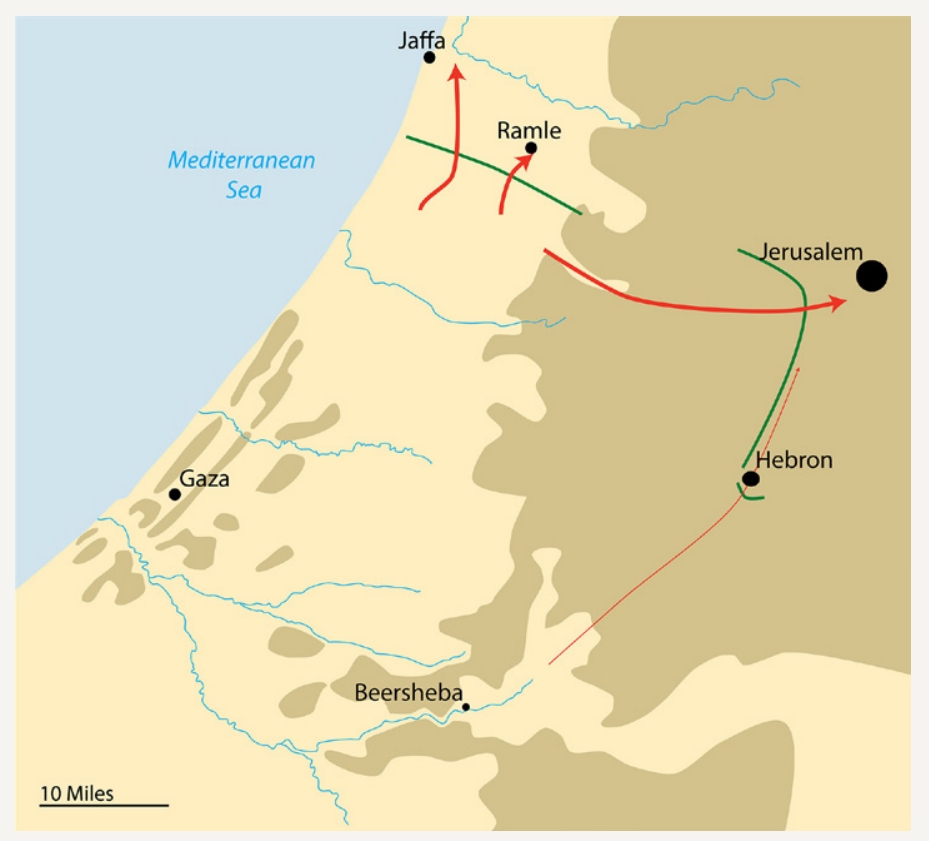

Figure 3. In the final phase, the British forces conducted a deliberate advance into the Judean Hills, occupying Jerusalem on 9 December.

allow for timely analysis and distribution of relevant data. In the third phase of the battle the EEF began a slow and deliberate eastward advance into the Judean hills, which resulted in the capture of Jerusalem on 9 December (Figure 3). As the Turkish army was too battered at this point to effectively counter the British advance, the purpose of the operation maps in this phase appears to have changed, with the maps becoming a historical record meant to communicate the EEF's accomplishments to an external audience (Collier 2008, 13).

\section{THE EEF CARTOGRAPHIC SYSTEM}

The first step in applying the modified framework to the EEF's structure is to define the elements in this force that engaged in the information-gathering phase of the military cartographic system (see Table 3 ). These included the infantry and cavalry units that conducted ground patrols to ascertain the positions of the opposing Turkish force as well as their aerial counterparts in the Royal Flying Corps (RFC). Furthermore, the EEF employed technical means to gather information about their enemy, including intercepted Turkish wireless messages and reports from agents behind the lines. While each of these sources excelled at providing different types of information, the most profitable source of intelligence appears to have been the statements of Turkish deserters who left their units to seek asylum with the British army, and the broadly similar statements of prisoners captured during combat operations.

The data generated by these patrols, intercepts, and interrogations took the form of reports sent back to the EEF General Headquarters (GHQ) by scouting elements (found in the war diaries of the relevant units in the British National Archives, collection WO 95 for ground units and AIR 1/2210/209/26/2 for RFC patrols), intercepted messages (some preserved in the Gerard Clauson Papers at the British Imperial War Museum, London), and notes gleaned from the interrogation of deserters (WO 157/717 through WO 157/722). As in the more generalized military framework (Table 2), these disparate raw data required further analysis by the EEF's staff to transform them into useful information before they could inform a coherent picture the Palestine front.

In the information-processing phase of the mapping cycle the GHQ staff attempted to compile and analyze the information arriving from these diverse sources to produce operationally useful intelligence for the unit commanders. Staff officers gathered these data into daily intelligence summaries (WO 157/717 through 722) in which they synthesized this information into a coherent whole. These daily summary documents represent a clear link between the information gathered by the EEF reconnaissance forces and the operation maps insofar as specific entries in the intelligence summaries appear regularly as symbols and annotations on the maps.

Another facet of this information-processing effort appears to have been the creation of draft operation maps (Figure 4), which were used to track and analyze the data received at GHQ during the day (Meinertzhagen 1960, 225). These draft maps differed from the final daily editions in that they were unpolished and only showed the positions of the British forces while ignoring their Turkish opponents. These draft maps were intended to inform the central product of the mapping cycle: the daily operation maps printed during the document-distribution phase.

In the third phase of the EEF's cartographic cycle, the GHQ staff intelligence officers submitted the latest copies of their daily draft maps to the draftsmen of the $7^{\text {th }}$ FSC for copying and printing. These draftsmen created colored plates for overprinting the red (British) and green (Turkish) unit symbols onto pre-printed base maps (Maule 1919, 13). This process occurred each evening, 


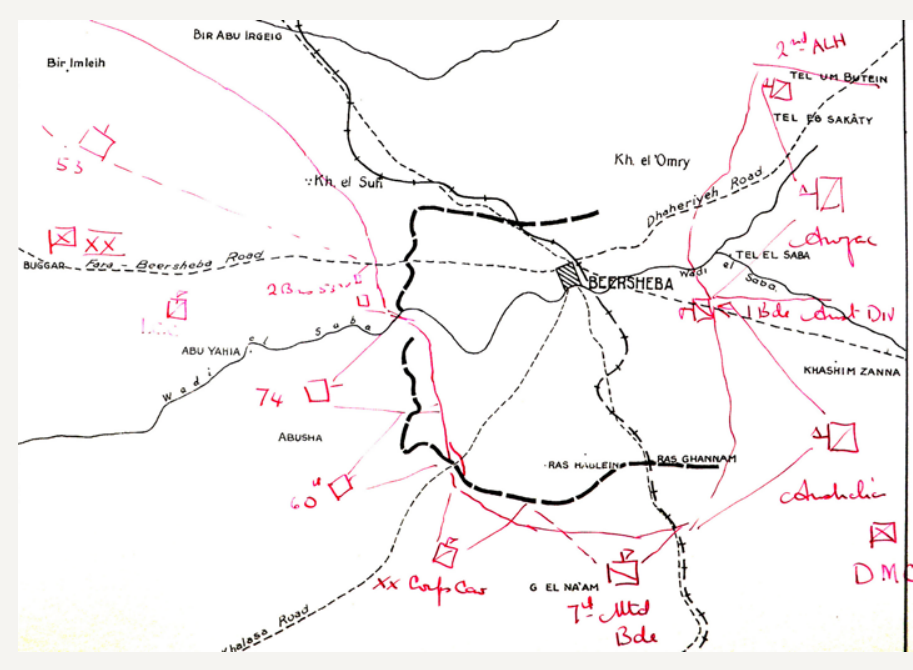

Figure 4. An excerpt from a draft operation map drawn during the opening day of the Gaza offensive. Note the obviously handdrawn symbols and that the map only shows British units, omitting Turkish positions. (TNA WO 153/1035/2).

with the draft maps delivered to the $7^{\text {th }} \mathrm{FSC}$ at $4 \mathrm{pm}$ and the final polished copies available for distribution at $6 \mathrm{pm}$ (Meinertzhagen 1960, 225). The maps were then delivered by courier to the EEF's corps and division commanders, with enough copies printed to supply at least one map to each unit, with additional copies retained at EEF GHQ and at the $7^{\text {th }}$ FSC ( $7^{\text {th }}$ FSC War Diary, entries for 28 October through 9 December). These maps would have accompanied orders sent by GHQ to its subordinate headquarters, which were themselves informed by the freshly produced maps.

In the final phase of this specialized cartographic framework, the EEF GHQ as well as its subordinate corps and division commanders, used the operation maps to make decisions about forthcoming maneuvers. One clear example of such document use occurred in the early stages of the battle. The 2 November operation map showed strong Turkish reserves moving to the far eastern flank to counter the British advance, a movement that helped prompt the start of the British attack at the western end of the line (Figure 5). However, higher level officers at GHQ, worried that the maps would discourage the British commanders at the eastern end of the line from aggressively pursuing their own attacks, ordered these maps retracted (Meinertzhagen 1917, 46). Accordingly, the 3 November map showed the Turkish reserves back in their original locations, though now represented by hollow box symbols to denote uncertainty about the location of the Turkish units (Figure 6).

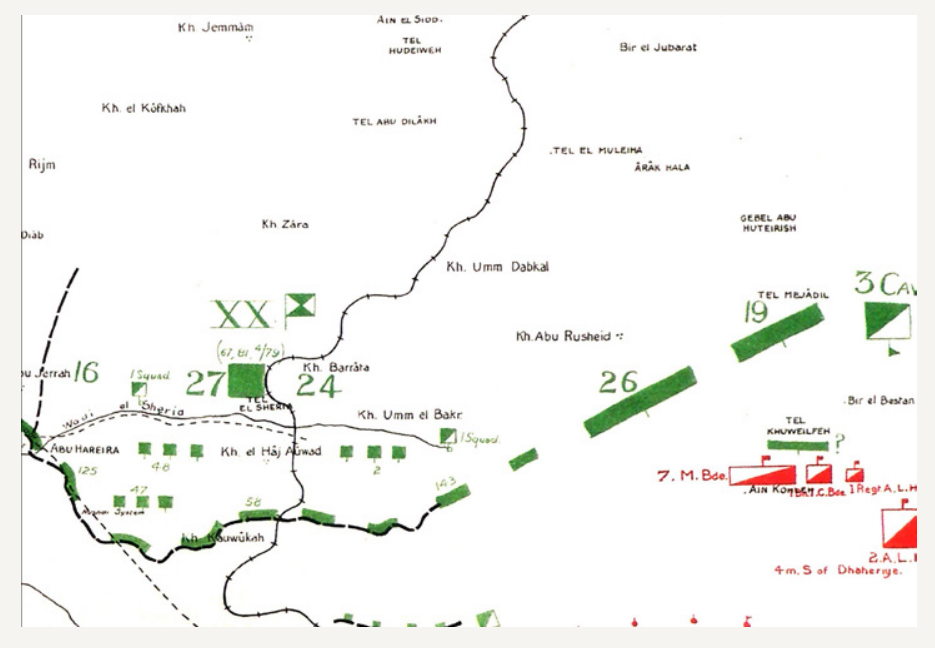

Figure 5. Facsimile excerpt from the 2 November operation map that shows a strong Turkish reinforcement of their eastern flank to counter the British attack there. Note in particular the 19th and 26th Divisions to the right represented by large rectangles presumably denoting strong formations. The horizontal dimension of this figure is approximately 25 kilometers (TNA WO 153/1035/2).

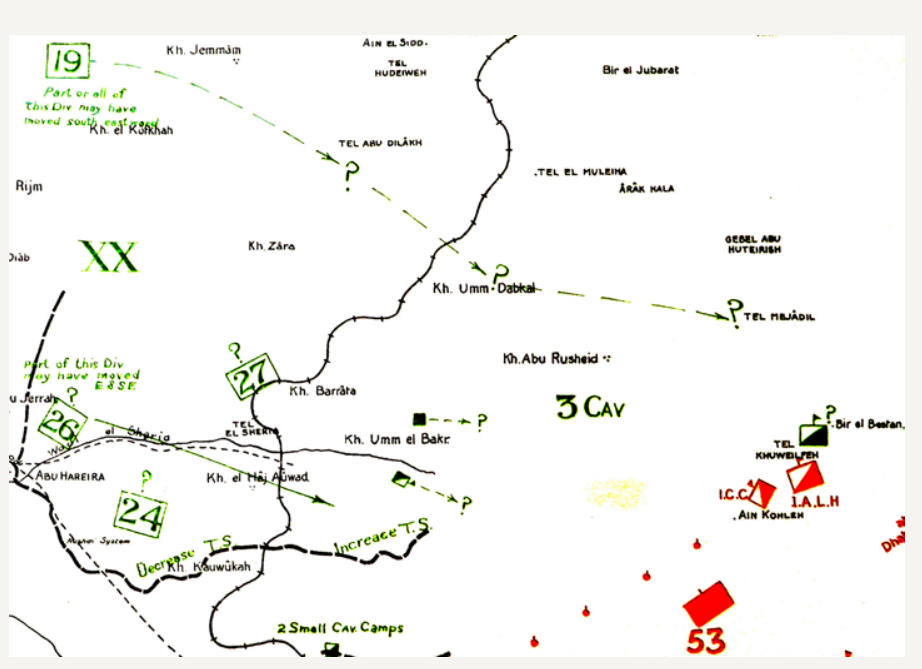

Figure 6. Facsimile excerpt from the 3 November operation map that shows the same area as Figure 5. Note that the symbols representing Turkish reserve formations have been removed back to their original locations behind the line (left side of the figure) and are now marked by hollow box attenuation symbols. The horizontal dimension of this figure is approximately 25 kilometers (TNA WO 153/1035/2).

This episode illustrates that the operation maps influenced decisions made by the EEF's commanding officers both at the GHQ and the corps level. These decisions guided the movements of British forces and patrols, maneuvering them into positions where they could observe their Turkish opponents (or not, in many cases) and report 
information back to their higher headquarters, beginning anew the cartographic cycle that would produce the next day's iteration. Moreover, the EEF staff likely considered the operation mapping technique to be successful because they reintroduced it in an improved form during Allenby's final 1918 offensive. Furthermore, James T. Kelly, a US army officer writing in 1933, suggested that the American military was modeling their intelligence maps after the $7^{\text {th }}$ FSC operation maps, demonstrating an even broader influence (Kelly 1933, 42-43).

The process of conceptually organizing the EEF in this way revealed the important roles played by even minor entities within the British army, including units that would not have participated directly in either reconnaissance or mapmaking. For example, one vital element of the EEF cartographic system was the communication troops who, by their efforts in setting up signal networks, largely controlled the amount and type of information that could reach the staff at GHQ. The EEF's intelligence staff could only map information received from those involved in information gathering. The link between the information-gatherers and the staff was often tenuous and restricted, particularly during mobile operations, when the communication infrastructure was usually too slow to keep pace with the advancing formations. The evidence relating to how the maps were actually used in the final phase of the framework shed light onto their intended purpose, another facet of this subject that would have remained unclear under a more narrow examination restricted solely to map content.

This case study demonstrates how a version of Woodward's framework can frame the study of a specific episode of historical military cartography. In the case of the EEF, this framework is useful for understanding the entire cartographic process and drawing conclusions about the mapping cycle's purpose and effectiveness. Indeed, it highlighted the fact that the EEF's twenty-four hour cartographic cycle, suited for graphically organizing a stable front as existed prior to the start of the British offensive, was too slow to cope with the rapidly changing operational conditions of mobile operations such as those in the second phase of the battle. Finally, this conceptual organization highlights the similarity of the EEF's cartographic activity to present-day digital mapping systems.

\section{CONCLUSIONS}

\section{APPLICATIONS TO MILITARY CARTOGRAPHY}

WOODWARD's (I974) SUGGESTED FRAMEWORK is an excellent tool for examining military mapmaking, as long as certain limitations are recognized. For the framework to be fully appropriate, the military unit studied should be of sufficient size and capability to conduct all phases of the mapping cycle, from information gathering through document use. During World War I this capability was generally held at the army level of organization because these formations were the smallest to possess the drafting and printing equipment necessary for map production. In present-day militaries, the ability to conduct a complete cartographic cycle occurs as low as the battalion level. In each case, lower-level organizations participate in portions of this framework, often making their own simple maps in the process. As an example, junior sergeants in the US Army are trained to draw crude maps in the dirt to rapidly communicate plans to the two or three soldiers they lead, and young officers are expected to produce rough terrain models in the field to brief their platoons and companies on planned operations.
Of course, the maps produced by these systems are imperfect representations of reality, with their own silences, white lies, and inaccuracies that detract from their fidelity as records of the actual course of the battle (Robinson and Petchenik 1977, 101; Monmonier 1991, 1-4; Harley $1989 \mathrm{~b}, 84-85)$. In the case of the EEF operation maps, the editions printed during the mobile second phase of the Gaza offensive were nearly useless from a tactical perspective because they simply did not communicate much usable information, and what data they did show were largely based on speculation by the intelligence staff. But even in such circumstances, Woodward's framework demonstrates that examining an army as an integrated, cyclical cartographic system can be important in trying to understand what the cartographers didn't know, why they didn't know it, and how they attempted to graphically communicate uncertainty.

If these limitations are recognized, the utility of Woodward's framework in this context becomes obvious. Large military units, at least since World War I, have 
acted as cartographic systems that rapidly gather, process, and plot spatial information, and then use the resulting maps to plan and execute operations. These operations in turn generate further information that must be mapped and distributed. Whereas only portions of this cartographic cycle may be relevant to most civilian mapping activities, the entirety of the framework comes into play in the military context. While this case study is an example of historical military cartography, this method is just as useful-perhaps more so-for studying contemporary military cartography.

\section{FURTHER APPLICATIONS}

The method of considering military units as cartographic systems suggests applications that reach beyond combat operations. Furthermore, such contemporary applications need not be restricted to military organizations. One obvious example of a potential application of Woodward's framework is the response to the Fukushima reactor disaster in Japan, where the spread of radiation-contaminated water needed to be mapped continuously and appropriate action taken to protect potential victims. Another example is the use of mapping in response to an epidemic to ensure efficient distribution of vaccines or the management of a quarantine.

On the other hand, the Woodward framework may be of more limited utility in studying or designing more decentralized crowd-sourced or big-data mapping systems such as OpenStreetMap or Google's influenza mapping algorithms. In these systems many or all elements of the cartographic process may be ill-defined and difficult to incorporate into the framework's structure (Bennett 2010, 8). Even so, some of these cartographic activities seem to be showing a movement towards more centralized control of information processing as well as privileging certain types of information gathering to improve the map products' accuracy and utility (Butler 2013). In these circumstances, Woodward's framework is still a valuable tool for analyzing these systems, at least in part.

To conclude, research into historical and contemporary military cartography provides a context where scholars can make fuller use of Woodward's framework. Indeed, further examinations of the prodigious mapmaking activities of military organizations can enrich academic cartography (Harley and Woodward 1989, 11-13). As Edney noted in his essay about Woodward's impact on academic cartography, "To understand map making and map use as human endeavors requires consideration of all mapping endeavors and not just those which contributed to the present-day concerns of academic cartography" (Edney 2005, 22). Military cartography is one of these endeavors that requires further research, and Woodward's suggested framework is an excellent tool for the job.

\section{ARCHIVAL MATERIALS}

7th Field Survey Company. 1917. Situation Maps. British

National Archives, TNA WO 153/1035/2 and WO 153/1043.
Egyptian Expeditionary Force. 1917. Intelligence Summaries. British National Archives, TNA WO 157/717 through WO 157/722.

1917. War Diary. British National Archives, TNA WO 95/4409.

\section{REFERENCES}

Armenis, Damien. 2010. "An experiment on the utility of blue force tracker: the costs and benefits of having God's eye view." International Journal of Intelligent Defence Support Systems 3: 207-224. doi: 10.1504/ IJIDSS.2010.037091.
Bennett, Jonathan. 2010. OpenStreetMap: Be Your Own Cartographer. Birmingham, UK: Packt Publishing.

Butler, Declan. 2013. "When Google got flu wrong." Nature 494: 155-56. doi: 10.1038/494155a. 
Collier, Peter. 1994. "Innovative military mapping using aerial photography in the First World War: Sinai, Palestine and Mesopotamia 1914-1919.” The Cartographic Journal 31: 100-104. doi: 10.1179/ caj.1994.31.2.100.

2008. "Not just trench maps." Paper presented at the Symposium of the Commission on the History of Cartography in the 19th and 20th Centuries, Portsmouth, UK, September 10-12.

Collier, Peter, and Rob Inkpen. 2001. "Mapping Palestine and Mesopotamia in the First World War." The Cartographic Journal 38(2): 143-54. doi: 10.1179/ caj.2001.38.2.143.

Edney, Matthew H. 2005. "Putting 'cartography' into the history of cartography: Arthur H. Robinson, David Woodward, and the creation of a discipline." Cartographic Perspectives 51: 14-29. doi: 10.14714/ CP51.393.

Fedman, David, and Cary Karacas. 2012. “A cartographic fade to black: mapping the destruction of urban Japan during World War II." Journal of Historical Geography 38(1): 306-28. doi: 10.1016/j.jhg.2012.02.004.

Finn, Michael P., and Diana Thunen. 2013. "Recent literature in cartography and geographic information science." Cartography and Geographic Information Science 40(1): 363-81. doi: 10.1080/15230406.2013.819201.

Freundlich, Beth. 2011. "The history of cartography project." Cartography and Geographic Information Science 38(3): 341-43. doi: 10.1559/15230406382341.

Hammond, Grant. 2004. The mind of war: John Boyd and American security. Washington DC: Smithsonian Institution.

Harley, J. B. 1989a. "Deconstructing the map.” Cartographica 26(2): 1-20. doi: 10.3138/ E635-7827-1757-9T53.

1989b. "Historical geography and the cartographic illusion." Journal of Historical Geography 15(1): 80-91. doi: 10.1016/S0305-7488(89)80066-0.
Harley J. B., and David Woodward. 1989.

"Why cartography needs its history." The

American Cartographer 16(5): 5-15. doi:

10.1559/152304089783875604.

Kelly, James T. 1933. A Study of the Operations of the British Intelligence Section of the Egyptian Expeditionary Force, in the Palestine Campaign, Under the Command of Sir Edmund H.H. Allenby, G.C.B. Fort Leavenworth, Kansas: Command and General Staff School.

Maule, W. J. 1919. Report on the Work of the Seventh Field Survey Company, R.E.: Egypt, Sinai, Palestine and Syria. Unpublished report to G.S.G.S. Map Research and Library Group DMS, Tolworth.

McGeachan, Cheryl. 2014. "Historical geography I: what remains?" Progress in Human Geography 36(8): 824-37. doi: 10.1177/0309132514546449.

Meinertzhagen, Richard. 1917. Meinertzhagen Diary, Volume 20. Unpublished collection held at Rhodes House, Oxford, UK.

1960. Army Diary 1899-1926. Edinburgh and London: Oliver and Boyd.

Moellering, Harold. 1980. "Strategies for real-time cartography.” Cartographic Journal 17: 12-15. doi: 10.1179/caj.1980.17.1.12.

Monmonier, Mark. 1991. How to Lie with Maps. Chicago: University of Chicago Press.

_. 2007. "Cartography: the multidisciplinary pluralism of cartographic art, geospatial technology, and empirical scholarship." Progress in Human Geography 31(3): 371-79. doi: 10.1177/0309132507077089.

Mostaghni, Michael. 2010. "OODA loop: setting a pattern may not always be a bad idea." Infantry 99: 49-50.

Muehrcke, P. C. 1972. Thematic Cartography. AAG Resource Paper No. 19. Washington, DC: AAG. 
Pearson, Alastair. 2002. "Allied military model making during World War II." Cartography and Geographic Information Science 29(3): 227-41. doi: 10.1559/152304002782008468.

Pulsipher, Lydia M. 1987. "Assessing the usefulness of a cartographic curiosity: The 1673 map of a Sugar Island." Annals of the Association of American Geographers 77: 408-422. doi: 10.1111/j.1467-8306.1987. tb00167.x.

Robinson, Arthur H. and Barbara Bartz Petchenik. 1975. "The map as a communication system." Cartographia 14: 92-110. doi: 10.3138/0235-6117-1TW6-06T5.

Schulten, Susan. 2012. Mapping the Nation: History and Cartography in Nineteen Century America. Chicago: University of Chicago Press. doi: 10.7208/ chicago/9780226740706.001.0001.

Sheffy, Yigal. 1998. British Military Intelligence in the Palestine Campaign. London: Frank Cass.
US Army. 2004. Field Manual 101-5-1: Operational Terms and Graphics. Washington, DC: Headquarters, Department of the Army.

US Army. 2010. Field Manual 5-0: The Operations Process. Washington, DC: Headquarters, Department of the Army.

US Army. 2012. Army Doctrine Publication 5-0: The Operations Process. Washington, DC: Headquarters, Department of the Army.

Wavell, Archibald P. 1936. The Palestine Campaigns. London: Constable.

Woodward, David. 1974. "The study of the history of cartography: a suggested framework." American Cartographer 1:101-115. doi: 10.1559/152304074784107746.

Woodward, Rachel. 2014. "Military landscapes: Agendas and approaches for future research." Progress in Human Geography 38(1): 40-61. doi: $10.1177 / 0309132513493219$. 